\title{
A Mountain in the Prairies - the Riding Mountain Biosphere Reserve, Manitoba, Canada
}

\section{Christoph Stadel}

Keywords: Biosphere Reserves, Canadian Prairies, Riding Mountain National Park, agricultural-recreational landscapes, rural development

\section{Abstract}

When one approaches Riding Mountain from the east and north, this segment of the Manitoba Escarpment rises steeply from the flat plain of the former glacial lake Agassiz to form the Second Prairie Level. To the south and west, though, Riding Mountain gently blends into the adjacent morainic landscapes. For the native Anishinabe, Wagiiwing (Riding Mountain) represented a "vision of a mountainous landscape that holds everything the many creatures depend upon for survival and sanctuary" (Parks Canada 2007: 5). Early European colonists and contemporary local residents have always considered this section of the Manitoba Escarpment a mountain with a distinct individuality and specific geomorphological and ecological features.
Profile

Protected area

Riding Mountain BR

Country

Canada

\section{Biosphere Reserves in Canada}

Of the 621 Biosphere Reserves (BRs) in 117 countries worldwide, 16 are located in Canada. Riding Mountain, Manitoba, and Redberry Lake, Saskatchewan, are the two BRs located in the Prairie region (Figure 2). Waterton in the Canadian Rocky Mountains, Mount Arrowsmith on Vancouver Island, Manicougan-Uapishka in the Central Laurentian Mountains, the old volcano of Mont St. Hilaire in Quebec, the Niagara Escarpment and Riding Mountain, are BRs with mountainous traits.

In Canada the first BRs were established in 1978. The first BR was Mont Saint-Hilaire in Quebec, the latest one, established in 2011, is Bras D'Or Lake in Nova Scotia. The National Action Plan for Biosphere Reserves in Canada (Canada/MAB, Canadian Commission for UNESCO 1987) documented 15 principal ecozones of Canada as a basis for future selection of BRs. Most noticeable, and in the view of this author deplorable, is the complete absence of any BR in the vast territory of northern Canada. The target of representing each of the major ecozones of Canada was never achieved, although this goal is still not completely forgotten.

BRs in Canada are highly diverse in size, shape, ecological and human identity. Initially the BRs in Canada focused on ecological learning processes. At a later stage the component of social learning was added to the ecological goals. In this way the participation of the various stakeholders and social groups of the region were considered crucial in the conservation and sustainable development initiatives. The postulates of ecological learning and social learning are not mutually exclusive; they co-exist and complement each other (Schultz et al. 2010).

The BRs in Canada have three principal functions:

1. They contribute to the conservation of ecosystems and to the preservation of the cultural heritage;

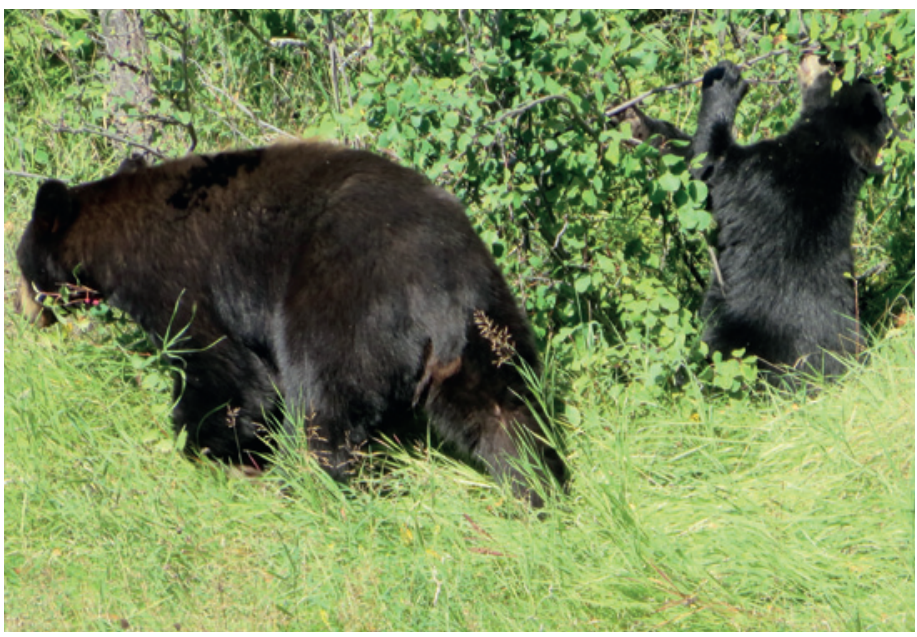

Figure 1 - Bears, Riding Mountain National Park. (C) C. Stadel

2. They foster the economic and social viability of the countryside and the livelihoods of local people;

3. They contribute to the local and regional capacities for education, training, research, monitoring, networking and partnerships with respect to conservation and regional sustainable development.

The goal of social learning, in addition to the objective of biodiversity conservation (see Figure 1), underlines the importance of the viability of local livelihoods and the respect for the interests and responsibilities of local people, including those of indigenous populations. Borrini-Feyerabend (2002: 5) has correctly pointed out that indigenous people have made a significant contribution to the establishment and maintenance of conservation and sacred areas, long preceding the establishment of legally established protected areas. Yet today the local perception of and the attitudes towards protected areas are ambivalent or even controversial. Some communities may be proud of being part of a BR, may identify with it and may 


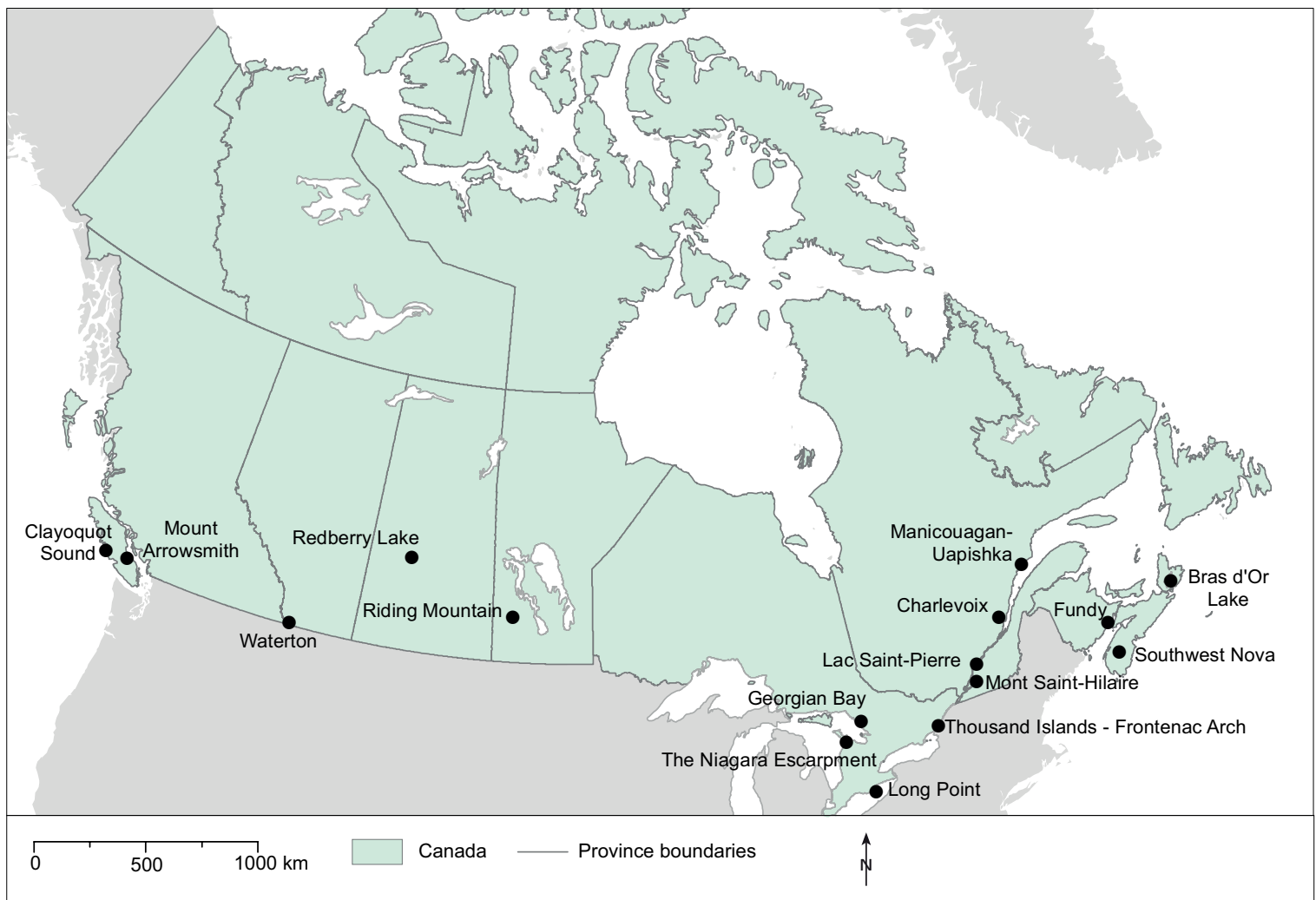

Figure 2 - Biosphere reserves in Canada. Source: modified by W. Gruber

benefit from being included into a BR, for instance by enhanced ecotourism opportunities. Others may perceive the BR as an alien, externally imposed administrative unit, hindering the exploitation of natural resources and regional development opportunities.

The BRs in Canada are represented and supported by the Canadian Biosphere Reserves Association (CBRA). The CBRA coordinates funding, projects, research, monitoring, education and training. In 2013 the CBRA cooperated in the compilation of "proven good practices in Canadian Biosphere Reserves" (The Canadian Commission for UNESCO 2013). This report presents projects relating to the broad themes of land management and ecosystem services, sustainable tourism and charters, and education, using most of the Canadian BRs as case studies.

\section{Riding Mountain BR}

The designation of Riding Mountain BR in 1986 post-dated the establishment of Riding Mountain NP in 1933, the current core area of the BR, by 53 years. Riding Mountain BR is located in the province of Manitoba, some $300 \mathrm{~km}$ northwest of the provincial capital Winnipeg. Its locational coordinates are approximately $50^{\circ} \mathrm{N}$ and $100^{\circ} \mathrm{W}$. The total area of Riding Mountain BR is 1331.8 square kilometres, with a core zone of Riding Mountain NP measuring 270.8 square kilometres, a buffer zone of 26.8 square kilometres, and a transition zone of the remaining 1034.2 square kilometres. Administratively, the core zone of
Riding Mountain NP is federally governed; the transition zone is administered by a total of 12 municipalities (as of 1 January 2015) surrounding Riding Mountain NP (Figure 3).

It is situated in the so-called Parkland region, a transition zone of grassland and aspen-oak and mixed wood forest biomes. Within Manitoba's prairie region, Riding Mountain BR represents a unique topographic, ecological and cultural landscape. Its altitudinal range extends from $304 \mathrm{~m}$ at the shore of Lake Dauphin to $755 \mathrm{~m}$ on Riding Mountain. As part of the Manitoba Escarpment, which stretches in a southeast-northwesterly direction across the province, it rises conspicuously in the east and north from the flat Manitoba lowlands. To the south and west, though, there is a gentle landform transition to the adjacent hummocky knob and kettle topography, some rather deeply entrenched glacio-fluvial channels, gently rolling moraines, and outwash plains.

Because of its higher elevation and the ensuing cooler and moister microclimate, the natural vegetation represents an ecological niche of different primarily forest biomes. The ecological island character of Riding Mountain was further enhanced by the fact that this terrain proved to be largely unattractive to agricultural colonization and European pioneer settlement at the end of the $19^{\text {th }}$ and the beginning of the $20^{\text {th }}$ centuries. It is therefore often euphorically described as an island of natural vegetation in a sea of buman-altered environments. But forestry and milling operations, as well as some haying and grazing on Rid- 


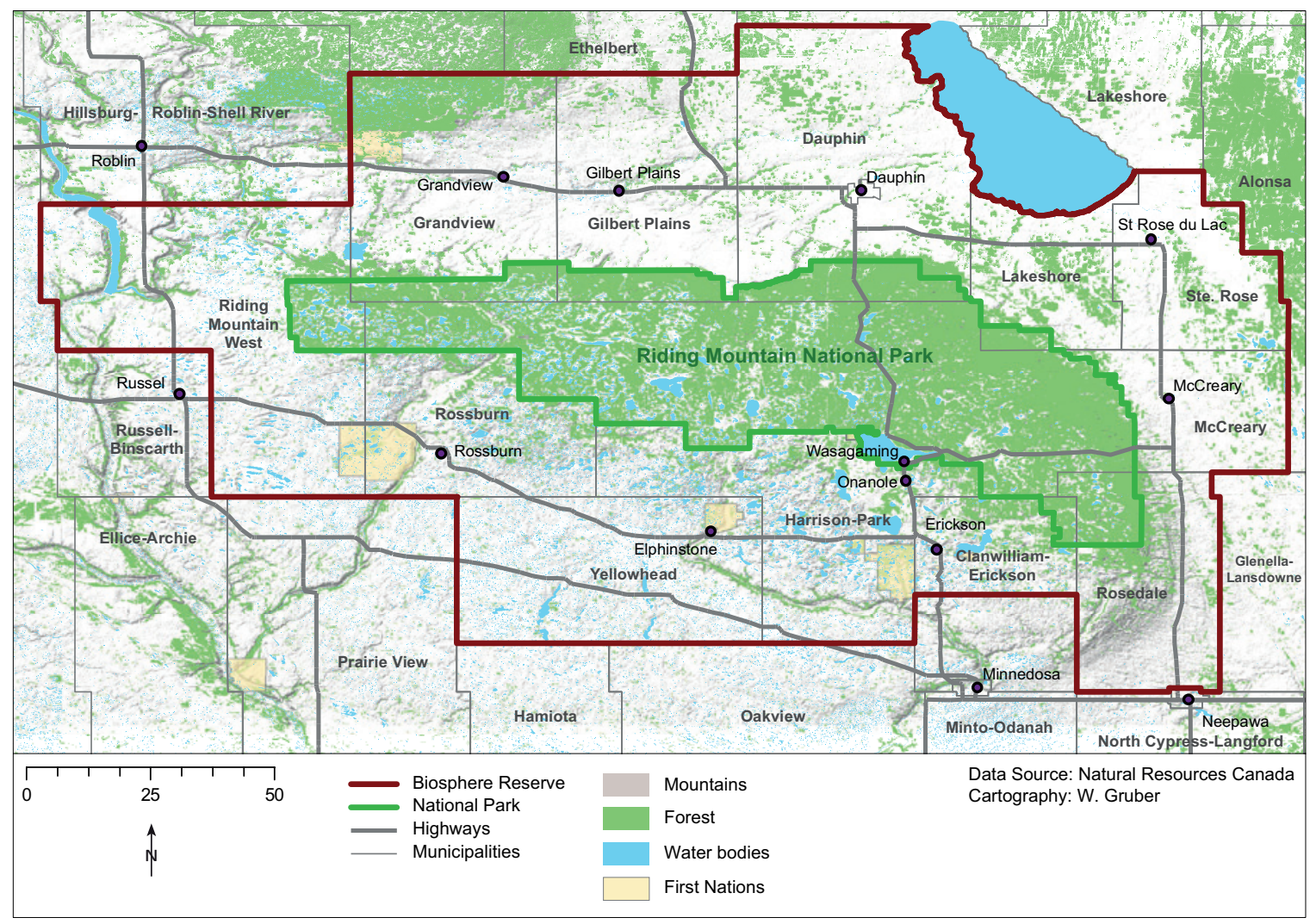

Figure 3 - Riding Mountain Biosphere Reserve. Source: modified and updated by W. Gruber

ing Mountain began as early as the 1870 s and supplemented early the agricultural activities in the vicinity. In 1895 the Riding Mountain Timber Reserve was officially established, to be designated in 1906 as a Forest Reserve. This activity continued even after the Forest Reserve became Riding Mountain NP in 1933. The last timber mill in Riding Mountain NP did not close until 1949.

The early European impact on Riding Mountain should not conceal the spiritual, cultural and economic significance of Wowwaswajicus (Hill of the Buffalo Chase) for the indigenous Cree and Assiniboine ethnic groups. To these communities Riding Mountain was a sanctuary and it gave them food and physical health (Canadian Parks and Wilderness Society 2004: 3-7). Indigenous people used the rich resources of the Riding Mountain region, hunting, trapping, fishing and picking berries and mushrooms, and also relying on the rich supply of fresh water, wood and pastures. With the advent of the fur trade and the establishment of early outposts of the Hudson's Bay Company in the $18^{\text {th }}$ and $19^{\text {th }}$ centuries, indigenous people participated in this economic activity.

The economic orientation and landscape of the Riding Mountain region was completely transformed in the second half of the $19^{\text {th }}$ century by four principal developments: The systematic land survey and land allocation of the section / township / range system initiated in 1869; the political integration of the Prairies into the Dominion of Canada; the building of colonization railways in the 1880s and 1890s; and the massive influx of European settlers. Under the Dominion Lands Act, the land with an agricultural potential was overlain by a grid of one square mile sections and larger six square mile township blocks and the corresponding gridiron network of roads. This provided the basis for the free grants of a quarter-section of land of 160 acres (around 65 ha) for prospective agricultural settlers (Stadel 1995: 144-145). The Canadian Northern Railway (formerly the Lake Manitoba Railway and Canal Company) was a critical stimulus for the pioneering settlement process of the Parkland region in the vicinity of Riding Mountain. By 1897 it reached the Valley River region to the north of Riding Mountain, where the town of Dauphin was founded. Both the land survey and the opening of the Prairies by railway lines generated a rapid and massive influx of European settlers. In the Riding Mountain region, different ethnic groups settled in specific areas and left a distinct imprint of material culture on the landscape. Apart from the British settlers occupying primarily the most fertile lands of Manitoba's south, non-AngloSaxon people fanned out to the lands further north. Therefore the Parkland belt in the vicinity of Riding Mountain became home primarily to French, Ukrainian and Scandinavian communities, giving Riding Mountain BR its special cultural imprint to date.

From the end of the $19^{\text {th }}$ century, the pioneer land became a rich agricultural realm of grain-growing and livestock farming (Figure 4), its settlement pattern 


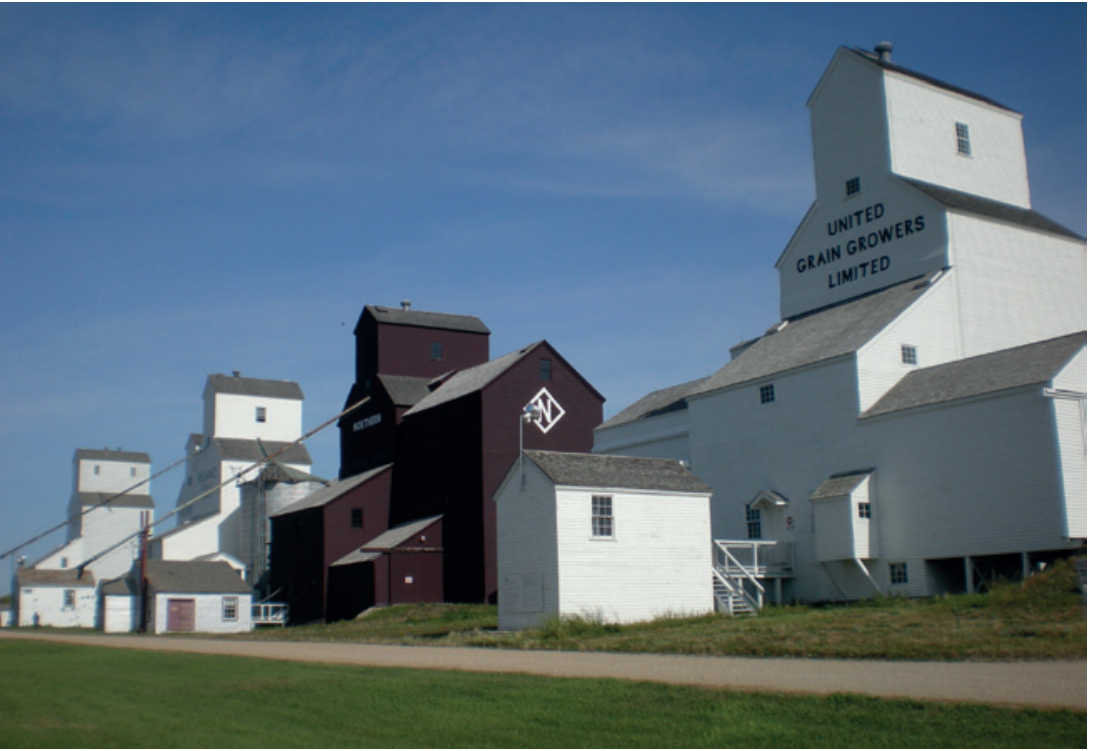

Figure 4 - Grain elevators at Inglis, Manitoba, now a $\mathrm{Na}$ tional Historic Site (C) C. Stadel

characterized by a combination of single farmsteads and a hierarchical system of service centres. In the course of the $20^{\text {th }}$ century and at the onset of the $21^{\text {st }}$ century, this is still the visual impression of the land, although a number of structural changes have impacted on farming and on the settlement fabric.

Quite early in the $20^{\text {th }}$ century the recreational potential of the lakes and forest of Riding Mountain was discovered, initially primarily by local people. Later they became the prime recreational hinterland of an expanding catchment area. Because the early cottages on the shores of Clear Lake, the largest lake of Riding Mountain, predated the establishment of Riding Mountain NP, this function of Riding Mountain NP gives it its special dual conservation-recreational identity (Stadel \& Selwood 1996: 318). Since the 1970s the recreational appeal of Riding Mountain has been boosted by the development of an ever-increasing number of cottage and second-home communities at the fringes of Riding Mountain NP (Figure 5), in response to growing numbers of outdoor leisure seekers, second-home owners, retirees and real estate speculators.

Riding Mountain BR has a low average population density of only 2.2 persons / square kilometre, or 2.8 if one excludes the core zone of Riding Mountain NP. The total population of 29758 people (2011 census) in the transition zone, has remained almost stable since 2006 (29776). But whereas the incorporated centres (the city of Dauphin, plus 6 towns and one village) increased by 616 people, the rural municipalities lost 631 individuals since 2006. In 2011 the Manitoba government legislated the amalgamation of municipalities with a 2011 population of less than 1000 to make local government more viable and cost effective. This amalgamation process has taken effect on 1 January 2015 and is shown in Figure 3.
Tasks, challenges and prospects for Riding Mountain BR

When Riding Mountain BR was established in 1986, the boundaries of the NP as its core zone had already been established for over half a century. The body entrusted with the areal designation of the BR was the Riding Mountain Liaison Committee (RMRLC), a forum to seek forms of regional integration of NPs and their neighbouring regions and communities with their principal agricultural and recreational economic orientation. Initially, 11 rural municipalities adjacent to Riding Mountain NP participated in this consultation process. In 1986 the NP was administered by the federal government, and 18 rural municipalities, towns and villages formed the proposed Riding Mountain BR within their existing administrative boundaries. They appoint a Biosphere Reserve Management Committee (BRMC) to run the activities of the BR. This spatial configuration is obviously a rather arbitrary delimitation which may not be in tune with naturally occurring ecological transition zones and buffer regions of protection and environmentally compatible sustainable economic activities. The situation is further complicated by the fact that most of the neighbouring First Nations have given rather lukewarm support to the aims and programmes of the BR, and also that most incorporated settlements have so far officially not joined the BR.

In Riding Mountain BR, the core zone of Riding Mountain NP fulfils a dual ecological protection / recreational tourism function (see Figure 1 and 6). As the NP is under federal jurisdiction, and because by and large only seasonal summer activities and residences are allowed, the goals of nature protection and ecological integrity are more easily implemented than in the outer transition zone. Nevertheless, even here conflicts may arise over certain human activities, their scale and the allocation of human and financial resources, especially during the peak summer season (Parks Canada, no year).

In the transition zone of the BR the situation is more complex and fluid. Here a triple political-jurisdictional framework of provincial, municipal and native First Nation competence and powers is at work. While Manitoba exercises a high degree of authority over many environmental, economic and social agendas, individual municipalities are responsible for specific land-use regulations, local taxes and municipal infrastructural services. Within Riding Mountain NP, the First Nation of the Anishinabe have been recognized as traditional stewards of this area and were allocated a piece of land around the north-western shores of Clear Lake - with a considerable degree of administrative autonomy and special hunting, fishing and landuse rights.

While declared objectives of BRs are ecological conservation and the encouragement of a sustainable regional economic and social development that is envi- 
ronmentally and socio-culturally compatible, divergent views and disagreements exist on how this may be attained. In particular, a crucial challenge is to find an acceptable balance between these aims and economic demands. For instance, the largely uncontrolled populations of bears, elk, moose and beavers are not contained within the boundaries of Riding Mountain NP, with the potential consequence of damaging agricultural land and crops. Also, a few years ago, an epidemic of elk tuberculosis infested the bovine population of the areas bordering on the NP. On the other hand, commercial hunters and trappers have established a number of hunting camps and have bait-lured wildlife out of the NP.

The transition zone of Riding Mountain BR is characterized by a rural agricultural economy of largescale field cultivation of predominantly wheat, canola and other commercial crops, as well as by large cattle operations. In the locations attractive to recreationists, non-farm secondary or increasingly also permanent homes have made their appearance, in some cases as single homes, but in recent decades especially as recreational subdivisions. These are found most prominently at the southern fringe of Riding Mountain NP. Here the landscape attributes of gentle rolling topography dotted with many small lakes and wooded areas, a lower agricultural potential compared to that of the other surrounding areas, the proximity to the resort of Wasagaming in Riding Mountain NP (Stadel 1996) and a good transportation link to the city of Brandon, as well as a certain social prestige factor have given this region a new functional orientation, visual appearance and socio-economic structure (Borgfjord 2010; Borgfjord 2011). In some municipalities, the councils are no longer exclusively dominated by local farmers and their interests; they are challenged by a new political class of urban newcomers with interests and agendas that may differ from the traditional rural-agricultural outlook (Stadel 2005). With this functional reorientation in parts of the transition zone has come a pronounced increase in land values, making it difficult for farmers to increase their agricultural acreages, or enticing them to give up farming, subdivide and sell off their land. In their turn, municipalities with a recreational appeal, have benefitted from substantial hikes in residential taxes, allowing for better infrastructures and services.

In sum, the structural attributes and the landscape of the Riding Mountain BR have undergone some major transformations and are highly complex and diversified: large-scale farms of individual families, Hutterite colonies and commercial companies; a hierarchical system of service centres, also undergoing some functional changes; the recreational space of cottages or retirement homes; and the NP and other conservation districts with their principal objective of environmental protection. Therefore Riding Mountain BR is today characterized and shaped by multiple interests, activities and stakeholders, which are a major challenge for

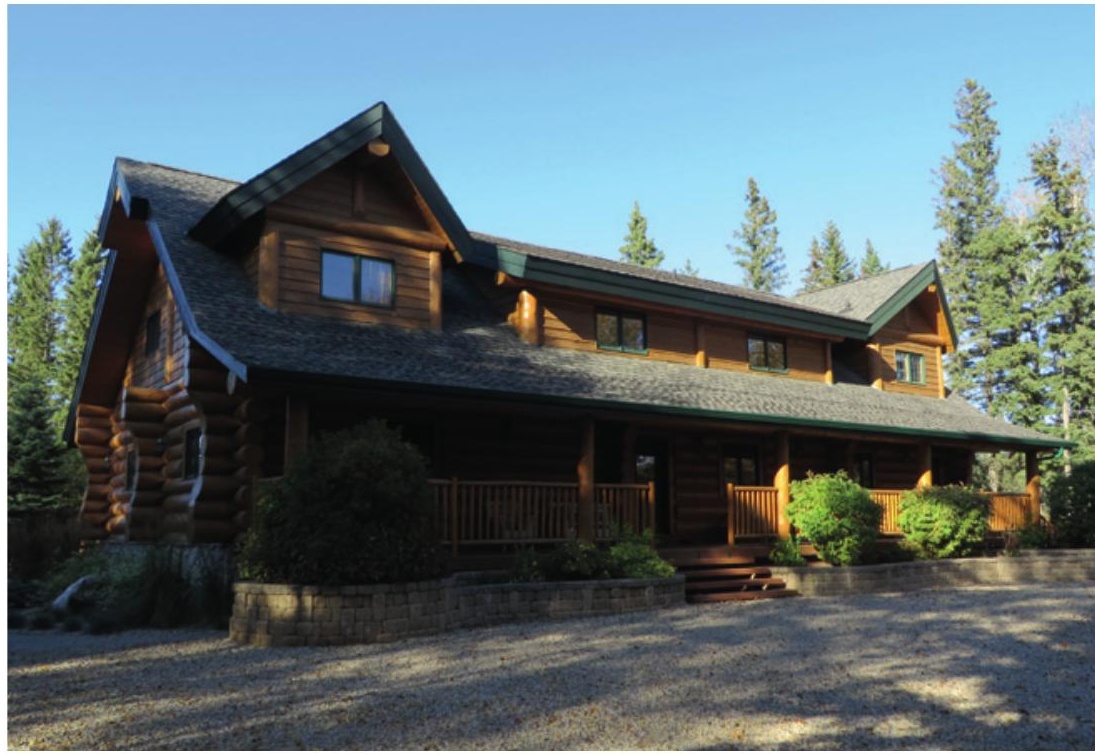

Figure 5 - Cottage in Onanole, at the southern fringe of Riding Mountain National Park (C) C. Stadel

cooperation and mutual agreement on the precise implementation of a sustainable regional development, as well as on the potential role of conservation within the web of various economic demands.

\section{Concluding remarks}

Riding Mountain BR is characterized by a great diversity of natural and human environments. Significant landscape contrasts are evident between the mountainous character of Riding Mountain, the gently rolling topography of the Parkland belt to the south and west, and the low-lying and flat plain of former glacial Lake Agassiz to the east and north. The landscape of the so-called zone of cooperation of the BR is dotted with a corollary of different hierarchical levels of service towns and is characterized by large-scale farming and recreational activities, especially in the lake and forest zones to the south. In contrast, Riding Mountain NP has a dual mandate for nature conservation and as a primarily summer destination for recreationists. In a political sense, the federal administration of Riding Mountain and the provincial-local authorities of towns and rural municipalities and of First Nations, may have at times divergent objectives and agendas but see each other also compelled to cooperate and to harmonize their goals and programmes.

While Riding Mountain BR is managed by a committee of representatives from Riding Mountain NP and the municipalities, towns and First Nations, the interest in and support of the BR is not shared equally by these stakeholders, and some of these local government bodies have so far opted to not commit themselves to an official membership. Another major problem of the BR is inadequate and uncertain funding. Despite these constraints, Riding Mountain BR was successful in launching a number of programmes 
with the triple objectives of environmental protection, ecologically compatible economic activities and educational initiatives to enhance public awareness of the BR and its aims. These include the Bovine Tuberculosis Management Programme, the Water Stewardship Project (Riding Mountain BR \& Centre for Sustainable Watershed 2012), efforts to reduce the spread of invasive species, fostering the heritage and cultural resources of the area, supporting local environmentallyfriendly economic activities like farmers' markets, as well as educational, recreational and ecotourism activities (The Canadian Commission for UNESCO 2013).

As one of the 16 BRs in Canada, and together with Redberry Lake in Saskatchewan, the unique BR in the Prairie Provinces, Riding Mountain BR has an important mandate for biodiversity and cultural conservation, environmental research, monitoring and education, and for ecologically compatible and sustainable land and water management and economic activities. A strong commitment by individual stakeholders, and local, provincial, federal and First Nation governments, is needed to instil into Riding Mountain BR sufficient vigour and vitality to meet current and future challenges.

\section{References}

Borgfjord, M.R. 2010. The South Riding Mountain Planning District. Management Plan. Onanole, Manitoba.

Borgfjord, M.R. 2011. The Park Municipal Development Plan. Onanole, Manitoba.

Borrini-Feyerabend, G. 2002. Indigenous and local communities and protected areas rethinking the relationship. Parks 12 (2): 8-15.

Brown, J. \& A. Kothari 2002. Editorial. Parks 12 (2): 1-3.

Canadian Commission for UNESCO \& Canada/ MAB. 2001. Riding Mountain Biosphere Reserve. Periodic Review Report 2000.

Canadian Parks and Wilderness Society 2004. Riding Mountain Ecosystem Community Atlas. Winnipeg

Parks Canada. No year: Wasagaming Community Plan. A Framework for Managing Land-use and Development in Wasagaming, Manitoba. Riding Mountain National Park.

Parks Canada 2007. Riding Mountain National Park of Canada and Riding Mountain Park East Gate registration Complex National Historic Site of Canada. Management Plan. Ottawa.

Price, M.F. 1996. People in Biosphere Reserves: an evolving concept. Society and Natural Resources: An International Journal 9(6): 645-654.

Riding Mountain Biosphere Reserve 2014. Hill of the Buffalo Chase. Riding Mountain Biosphere Reserve. Case for support. Onanole, Manitoba.

Riding Mountain Biosphere Reserve \& Centre for Sustainable Watershed 2012. Living by the Water's Edge. Riding Mountain Biosphere Reserve Water Stewardship Project. Onanole, Manitoba.

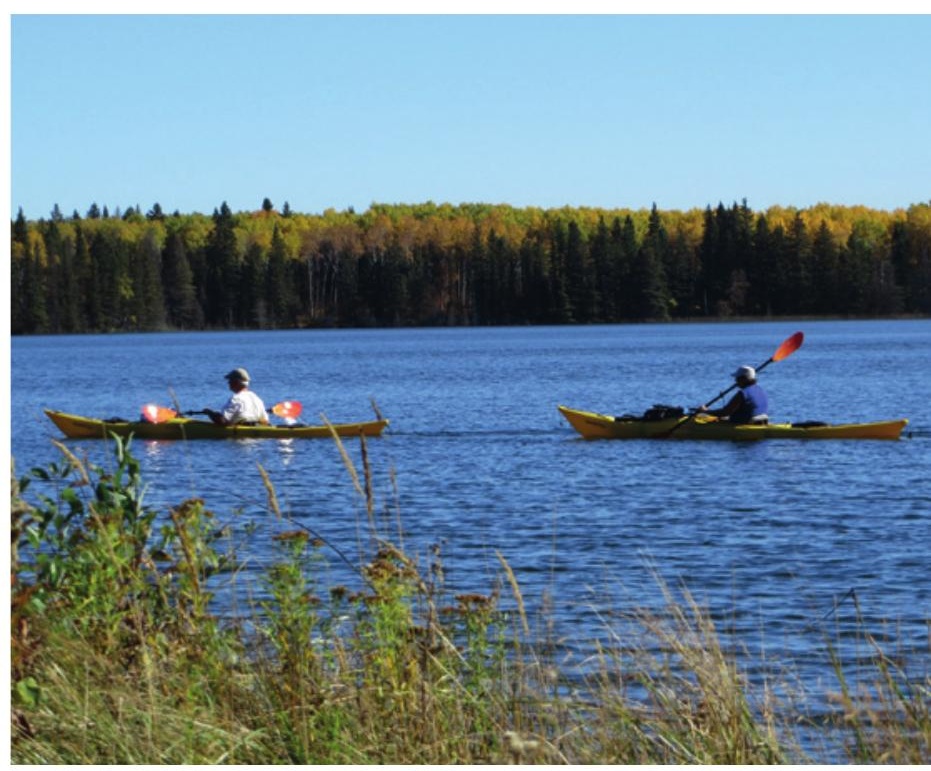

Figure 6 - Kayaking in Riding Mountain National Park. (C) C. Stadel

Schultz, L. et al. 2010. Learning from resilience? Exploring learning opportunities in Biosphere Reserves. Environmental Education Research 16 (5-6): 645-663

Stadel, C. 1995. Hauptphasen der europäisch beeinflussten Kulturlandschaftsentwicklung in der kanadischen Prärie. Salঝ̧burger Geographische Arbeiten 28: 141-155.

Stadel, C. 1996. The Seasonal Resort of Wasagaming, Riding Mountain National Park. In: Welsted, J., J. Everitt \& C. Stadel (eds.), The Geography of Manitoba. Its Land and its People. Winnipeg, 298-300.

Stadel, C. 2005. Rurbanisation de la campagne. Espaces récréatifs dans la region du Mont Riding, Manitoba, Canada. Revue Géographique de l'Est XLV (3-4): 187-194.

Stadel, C. \& J. Selwood 1996. Suburbia in the Countryside: Cottages and Cottage Dwellers in Canada. In: Steinecke, A. (ed.), Stadt und Wirtschaftsraum. Berliner Geographische Studien 44: 311-324.

The Canadian Commission for UNESCO 2013. Learning from each other: Proven good practices in Canadian Biosphere Reserves. Saskatoon.

\section{Author}

\section{Christoph Stadel}

is Professor Emeritus of the Department of Geography \& Geology of the University of Salzburg, Austria, and an Adjunct Professor of the Natural Resources Institute of the University of Manitoba, Canada. His research interests are focused on the Andes, the Canadian Prairies, comparative Mountain Geography and International Development. 